ISSN: 0213-2052 - eISSN: 2530-4100

DOI: https://doi.org/10.14201/shha202139377401

\title{
A DINASTIA VALENTINIANA NA HISTORIAE ADVERSUS PAGANOS DE ORÓSIO (VII, 32-35)
}

\section{The Valentinian Dynasty in the Historiae Adversus Paganos of Orosius (VII, 32-35)}

\author{
Janira Feliciano POHLMANN \\ Universidade Estadual Paulista, campus Franca \\ janirapo@yahoo.com.br
}

Fecha de recepción: 5-03-2021 Fecha de aceptación: 6-4-2021

ORCID: https://orcid.org/0000-0002-4204-2853

RESUMO: Mais de vinte anos após a morte de Valentiniano II, Orósio elaborou e propagou diferentes imagens para os imperadores da dinastia valentiniana. Através de análises realizadas na obra Historiae adversus paganos, escrita pelo presbítero no século V d.C., podemos conhecer um pouco destes personagens e, especialmente, perceber as mensagens que o autor desejava transmitir ao seu público. Sendo assim, o interesse deste artigo centra-se em saber de que maneira, através da retórica de Orósio, os indivíduos da dinastia valentiniana foram interpretados e que fatos o presbítero julgou serem pertinentes à redação de sua obra.

Palavras-chave: Orósio; Historiae adversus paganos; dinastia valentiniana.

RESUMEN: Más de veinte años después de la muerte de Valentiniano II, Orosio elaboró y propagó diferentes imágenes para los emperadores de la dinastía Valentiniana. A través de los análisis realizados en la obra Historiae adversus paganos, escrita por el sacerdote en el siglo V d. C., podemos conocer un poco de estos personajes y, sobre todo, comprender los mensajes que el autor deseaba transmitir a su público. Así, el interés de 
este artículo se centra en cómo, a través de la retórica de Orosio, se interpretaron los individuos de la dinastía valentiniana y qué hechos el presbítero juzgó pertinentes para la redacción de su obra.

Palabras clave: Orosio; Historiae adversus paganos; Dinastía Valentiniana.

ABSTRACT: More than twenty years after the death of Valentinian II, Orosius elaborated and propagated different images for the emperors of the Valentinian dynasty. Through analyses made in the work Historiae adversus paganos, written by the presbyter in the 5th century A.D., we can get to know a little of these characters and, especially, understand the messages the author wished to transmit to his audience. Thus, the interest of this article is centred on knowing in what way, through Orósio's rhetoric, the individuals of the Valentinian dynasty were interpreted and what facts the presbyter judged to be pertinent to the writing of his book.

Keywords: Orosius; Historiae adversus paganos; Valentinian dynasty.

\section{INTRODUÇÃO}

O século IV d.C. do Império romano foi marcado por figuras imperiais que receberam muita atenção em detrimento de outras. O que dizer de Constantino I (306/312-337 d.C. $)^{1}$, considerado o primeiro imperador cristão? E do imperador Juliano (355/360-363) e seu chamativo título "O apóstata». Teodósio I (379-395) e seu epíteto "O grande»! Todavia, nem todos os imperadores romanos ganharam destaques em documentos escritos após suas mortes e, menos ainda, em pesquisas atuais. Em meio aos nomes anteriormente citados, que receberam tantas luzes em sua época e continuam sendo objeto de estudos até hoje, os augustos da dinastia valentiniana governaram tanto as terras ocidentais como as terras orientais do Império de 364 a 392. Mais de vinte anos após a morte do seu último representante, Valentiniano II (375-392), o presbítero Orósio elaborou e propagou diferentes imagens para tais imperadores.

O estudioso de literatura clássica Andrew Laird destaca que os pesquisadores atuais analisam como as narrativas históricas utilizam a retórica, ou a linguagem persuasiva, para construir um significado e negam que estes escritos transmitissem mensagens inocentes ${ }^{2}$. Nesta conjuntura,

1. As datas deste artigo referem-se a Era Comum, por isso, deste momento em diante, dispensarei a abreviação «d.C.». As exceções serão marcadas pela abreviação «a.C.».

2. Laird, "The rhetoric of Roman", 2009, 197. 
interesso-me pelos argumentos escolhidos por Orósio para construir a imagem da dinastia valentiniana, em um momento en que a dinastia teodosiana administrava o Império romano. É certo que o autor também dissertou sobre outros augustos. Entretanto, o intuito deste artigo é examinar as ações e valores que o presbítero selecionou para narrar sua história sobre os governantes valentinianos. Como o autor construiu retoricamente as imagens destes indivíduos? Que fatos o presbítero julgou serem pertinentes à sua redação?

A obra orosiana em questão é o livro VII da Historiae adversus paganos (História contra os pagãos), provavelmente concluída em $417^{3}$, época em que Agostinho terminou a composição de sua De ciuitate Dei. Como Orósio expôs nas primeiras linhas do prólogo de seu livro I, esta obra atendeu a um pedido de Agostinho, bispo de Hipona, um seguidor do cristianismo niceno, como Orósio. Então, já pelo título e pelas indicações no início do livro, nota-se que a obra foi escrita contra os pagãos, para e por um indivíduo fiel à crença cristã nicena. A observação destes elementos é imprescindível para a análise das elaborações ali propostas. Afinal, assim é possível se aferir o público para o qual a obra foi escrita: os pagãos; e o ponto de vista daquele que escrevia: um defensor de uma determinada fé cristã, a nicena. Estes princípios nortearam a construção orosiana das imagens imperiais de Valentiniano I (364-375), Valente (364378), Graciano (367-383) e Valentiniano II.

A habilidade retórica de Orósio para elaborar tais imagens também foi considerada em meus estudos. Já em seu tempo, o presbítero hispano era conhecido por sua eloquência. Agostinho destacou que o sacerdote era "f́cil de palavra" e, na obra De uiris illustribus, Genadio o distinguiu como «varão eloquente»s. No mundo romano, o clássico orador Cícero defendera que a eloquência nascera da retórica ${ }^{6}$ e que estes elementos deveriam organizar palavras prazerosas adequadas à persuasão7. Sob estes parâmetros, observo que a retórica era aplicada para dispor as mensagens em um discurso de forma que o público (leitor e/ou ouvinte) compreendesse-as, disseminasse-as em seu dia-a-dia e as incorporasse em sua

3. Eustaquio Sanchez Salor afirma que os estudos sobre a data de composição da Historiae adversus paganos divergem. Alguns especialistas acreditam que ela foi iniciada antes da viagem de Orósio à Palestina, ocorrida entre 415 e 416, e terminada quando do seu retorno à África; outros defendem que ela foi redigida após esta viagem à Pelestina, neste caso, a redação teria ocorrido entre 416 e 417. En: Paulus Orosius, "Historias", 1982, 15.

4. Ag., Ep. 166, 2: «promptus eloquio».

5. Gen., De uir illustr., 39: «uir eloquens».

6. Cic., De Or. I, 32, 146.

7. Cic., De Or. I, 47, 213. 
cultura e na memória coletiva. Sendo assim, para se investigar as Historiae orosianas, a retórica deve ser observada, pois a mensagem desta obra está na construção da narrativa, na qual as afirmações teóricas servem a propósitos específicos ${ }^{8}$. Segundo o classicista Anthony John Woodman, a historiografia antiga possuía natureza retórica' ${ }^{9}$. Noto, então, que o estudo da retórica utilizada por Orósio para descrever os imperadores valentinianos é um caminho para se compreender as imagens que o autor edificou para tais governantes e que respostas e lições o sacerdote forneceu para seu contexto.

\section{Valentiniano I SOB a PENA de Orósio}

Orósio iniciou o parágrafo 32 de sua obra com a ascensão de Valentiniano I ao poder imperial. À esta informação, agregou a seguinte narrativa:

[Valentiniano I] Era um cristão que, sob o comando do augusto Juliano cumpria com íntegra fidelidade suas obrigações militares como tribuno dos escudeiros, quando a ele, o sacrílego imperador [Juliano], lhe ordenou ou que imolasse aos ídolos ou abandonasse a milícia; ele [Valentiniano I] saiu espontaneamente porque sabia fielmente que a justiça de Deus era grave e suas promessas melhores ${ }^{10}$.

As primeiras informações que Orósio disponibilizou para seu público a respeito deste imperador referia-se à crença professada pelo governante, a cristã, e ao banimento levado a cabo por Juliano, caracterizado pelo autor como «sacrílego imperador». O estrategista Amiano Marcelino, por sua vez, não mencionou este desentendimento entre Juliano e Valentiniano, todavia observo a atenção oferecida pelo autor aos acontecimentos de cunho militar. Além disso, é provável que o banimento de um tribuno - que se tornaria imperador - por parte de um augusto exemplar, como Juliano era considerado por Amiano, não fosse assunto para sua Res Gestae, uma vez que macularia as virtudes julianas. Tal banimento foi detalhado pelo cristão Sozomeno que também destacou a fé de Valentiniano e sua recusa

8. Van Nuffelen, "Orosius and the Rhetoric", 2012, 19

9. Woodman, «Rhetoric in Classical», 2004, 92.

10. Or., Hist., VII, 32, 2: "Qui cum Christianus integra fide sacramentum militiae gereret sub Iuliano Augusto tribunus scutariorum, iussus ab imperatore sacrilego aut immolare idolis aut militia excedere, fideliter sciens et grauiora Dei esse indicia et meliora promissa, sponte discessitw. 
em participar de um ritual de sacrifício juntamente com Juliano ${ }^{11}$. No início do século VI, o banimento de Valentiniano I por Juliano, movido por desentendimentos de crenças, foi relembrado pelo escritor e seguidor de crenças religiosas greco-romanas Zosimo ${ }^{12}$.

Com exceção de Amiano, escritores cristãos e não-cristãos registraram os conflitos religiosos que afastaram Valentiniano I do exército de Juliano. Na obra orosiana, depois da data da aclamação de Valentiniano pelo exército e de elucidar que este governante se manteve no trono por onze anos, as primeiras palavras para caracterizar o imperador foram: «Era um cristão» ${ }^{13}$. Saliento a importância desta identificação para o autor. Através de artifícios retóricos, o hispano contrapôs Valentiniano I e Juliano. Este augusto ganhou a alcunha de "sacrílego imperador", uma vez que impusera seus rituais, julgados profanos pelo autor, a um fiel cristão. A caracterização negativa esvaziava as ações julianas e, simultaneamente, proporcionava mais significado às obras valentinianas.

A historiadora Averil Cameron sustenta que, apesar das críticas de Amiano a Valentiniano I, o estrategista elogiou a tolerância deste augusto com relação às religiões professadas nas terras romanas ${ }^{14}$. A estudiosa das religiões Hajnalka Tamas esclareceu que alguns autores pagãos enalteciam a tolerância religiosa de Valentiniano I, enquanto os cristãos exaltavam-no como defensor do cristianismo, entretanto, nenhum destes autores nomearam-no christianissimus, epíteto oferecido aos seus filhos, Graciano e Valentiniano II, ainda em vida. A autora afirma que a construção da cristandade de Valentiniano I ganhou força a partir da redação da Passio Pollionis, uma obra escrita nas últimas duas décadas do século IV, na Panonia ${ }^{15}$. Esta distinção, que teria nascido em uma comunidade cristã da terra de origem de Valentiniano I, serviu aos propósitos de outros grupos cristãos que viam na figura imperial um modelo apropriado para disseminar o cristianismo entre os demais romanos. Orósio foi um dos autores que empregou tal noção no século V.

Para enfatizar ainda mais o cristianismo de Valentiniano I, Orósio declarou que o governante havia sido «recompensado por Cristo no lugar de seu perseguidor e recebido o poder de império» ${ }^{16}$. Com estas argumentações retóricas, Orósio edificou, destacou e propagou a parceria entre o

11. Soz., HE, VI, 6.

12. Zos., Hist., IV, 2, 2-3.

13. Or., Hist., VII, 32, 2: "Qui cum christianus",

14. Cameron, "El Bajo Imperio", 2001, p. 49.

15. Tamas, "Valentinian I, christianissimus", 2014, 83-84.

16. Or., Hist., VII, 32, 3: «retribuente Christo in locum persecutoris sui accepit imperium». 
governante do Império romano e Cristo. Ressalto que a vinculação entre uma figura divina e o imperador não foi uma inovação dos autores cristãos, uma vez que há muito tempo já fazia parte da tradição política dos romanos. De acordo com o historiador Paul Zanker, a elite romana tinha o costume de remeter suas origens a heróis e deuses gregos ${ }^{17}$. Uma estratégia que foi reaproveitada durante todo o período imperial desde Augusto, o qual se ligou a Apolo e chegou a vestir-se como o próprio deus para participar de um banquete ${ }^{18}$.

A criação e manutenção de laços entre o governante e os deuses integrava o arcabouço de legitimação do poder imperial, por isso foi reelaborada e alimentada por imperadores e escritores cristãos. Segundo o classicista Giorgio Bonamente, Eusébio de Cesareia, em suas obras Vita Constantini e Historia Ecclesiastica, criou uma teologia que tornava compatível a divinização tradicional greco-romana e a figura de um imperador cristã ${ }^{19}$. E tal elemento discursivo passou, então, a ser adotado por muitos autores eclesiásticos. Uma observação importante: mesmo que os estudos atuais analisem a estratégia discursiva e os usos sócio-políticos destes vínculos, noto que estas elaborações faziam parte das crenças e do modo de vida das pessoas daquela época. Apesar de serem elementos que auxiliavam no controle social, na manutenção de um determinado status quo e erigiam identidades integradoras, ao passo que excluíam certos grupos, estas noções compunham elementos culturais - e bastante práticos essenciais para o convívio dentro daquela sociedade.

Inserido neste grupo de autores cristãos que elaboravam e anunciavam a aliança entre o augusto e o Deus cristão, estava Orósio. Conforme o trecho destacado anteriormente, o autor vinculou Valentiniano I à escolha de Cristo, afinal, o governante teria sido "recompensado por Cristo" quando ascendeu à posição de augusto. A elaboração e a difusão destes laços persuadiam o público a aceitar e desejar este governante protegido pela divindade una. Tal discurso, simultaneamente, validava ainda mais o poder e a necessidade de um imperador cristão.

Além da opção religiosa do imperador, as ações militares de Valentiniano também tiveram lugar garantido na Historiae adversus paganos, mas em proporções variadas. O autor fez uma curta menção ao enfrentamento do imperador contra Procópio ${ }^{20}$, um parente do falecido imperador

17. Zanker, "Augusto», 2005, 66

18. Suet., Aug., 70.

19. Bonamente, «Teodosio il Grande», 2014, 19-20.

20. Or., Hist., VII, 32, 4. 
Juliano que tentara requerer para si o poder imperial nas terras romano-orientais.

Símaco, contemporâneo às batalhas travadas entre Valentiniano I e Procópio, dedicou cinco dos vinte e três parágrafos de sua Laudatio in Valentinianum Seniorem Augustum Prior para tratar do assunto ${ }^{21}$. Poucos anos após estes eventos, Amiano Marcelino registrou tais acontecimentos com sua atenção voltada às estratégias de confrontos e à formação de Procópio $^{22}$. Além destes registros escritos, certamente, estes eventos passaram a fazer parte da memória daquela sociedade. Portanto, não foi por falta de material e de conhecimento que Orósio restringiu sua alusão ao ocorrido. Foi uma seleção autoral. O foco do hispano não eram as atuações de Valentiniano I contra um usurpador. Para Orósio, os perigos eram outros, encarnados nos pagãos, como ressaltado no título de suas Historiae, nos cristãos que não compartilhavam os dogmas nicenos e nos estrangeiros que entravam em terras imperiais trazendo consigo suas crenças religiosas e culturas. As análises deste artigo estão centradas nestas duas últimas ameaças que pululam o texto orosiano destinado a tratar da dinastia valentiniana.

Observo que o sacerdote se preocupou em registrar a atuação de Valentiniano I contra tribos estrangeiras que ameaçavam territórios considerados romanos. Neste caso, o autor alegou que godos, saxões e burgúndios eram inimigos. Quanto aos saxões, Orósio destacou que foram derrotados por Valentiniano I em território franco ${ }^{23}$. Já a paz conseguida com relação aos burgúndios, para o autor, era fruto da conversão destes à fé católica, uma conquista alcançada pela "providência de Deus" (providentia Dei» ${ }^{24}$.

Enquanto a usurpação de Procópio ocupou apenas uma frase da Historiae adversus paganos, às ameaças impostas pelos estrangeiros o autor dedicou cinco parágrafos ${ }^{25}$. Nesta conjuntura, examino o contexto que impulsionou a redação desta obra. Estes livros foram escritos enquanto o presbítero estava em África, ou seja, longe da Península Ibérica, sua pátria. Conforme a historiadora Graciela Gómez de Aso, quando criança e em sua primeira adolescência, Orósio viveu em um cenário no qual o cristianismo prisciliano ganhou força e as terras ibéricas assistiam à entrada dos suevos. Neste ambiente, o presbítero sofreu represálias que o fizeram buscar refúgio em África, entre 410 e 415, para pedir conselhos teológicos

21. Sym., Laudatio in Valentinianum Seniorem Augustum Prior, 17-19, 21-22.

22. Am., Res Gestae, XXVI, 5, 1-10, 19.

23. Or., Hist., VII, 32, 10.

24. Or., Hist., VII, 32, 11-13.

25. Or., Hist., VII, 32, 9-13. 
a Agostinho, bispo de Hipona ${ }^{26}$. Além dos suevos, a partir de 409, populações alanas e vândalas também ingressaram na Península Ibérica.

Durante os séculos III e IV, as relações entre os romanos e as tribos estrangeiras intensificaram-se, fazendo com que muitos líderes estrangeiros ocupassem importantes funções na hierarquia militar romana ${ }^{27}$. A entrada destes povos em terras ibéricas levou a uma reestruturação sócio-política da Península e à transformação das sociedades hispano-romanas, que, pouco a pouco, tinham seus cargos públicos ocupados pelos novos moradores peninsulares.

Esta gente estrangeira ainda trazia consigo suas crenças religiosas vinculadas a antigas divindades ou mesmo crenças cristãs, contudo, não nicenas. Orósio, sendo um hispano-romano e um cristão niceno, certamente percebia este cenário como um ambiente desfavorável para viver, tanto que partiu para a África para buscar conselhos de Agostinho. Por isso, não é de se estranhar o realce que o autor ofereceu aos estrangeiros em sua Historiae adversus paganos, tratados como inimigos que deveriam ser combatidos pelo imperador, como ocorreu com os saxões, derrotados por Valentiniano I. De acordo com o historiador Peter Van Nuffelen, o bárbaro descrito por Orósio era uma figura de contraste, um elemento contrário ao ideal de civilização romana ${ }^{28}$. Novamente a retórica orosiana estava baseada em elementos de contraposição: o estrangeiro, materializado nos saxões, havia sido vencido e os romanos, liderados pelo augusto, alcançaram a vitória. Tais elaborações criavam uma imagem depreciativa para os grupos estrangeiros, ao passo que enalteciam a figura de Valentiniano I como um governante necessário aos romanos.

Orósio também adotou um outro caminho para tratar estes grupos: os inimigos estrangeiros poderiam se tornar aliados após a conversão ao niceismo, ou seja, à fé católica, como elucidou o autor no caso dos burgúndios. O filólogo Serafín Bodelón chega a nomear o presbítero como "filobárbaro" quando o autor descreve a possibilidade de alguns casos de reconciliação entre bárbaros e hispanos-romanos ${ }^{29}$. Percebo que a construção retórica sobre os burgúndios realizada pelo hispano tinha um pouco de filo, de amigável. Em seu estudo a respeito dos vândalos, T. Howe observa que os vândalos eram julgados de forma positiva quando eram católicos, mas que os estereótipos dos bárbaros eram aplicados a eles nos casos de perseguição dos católicos ${ }^{30}$. Nas argumentações retóricas de

\footnotetext{
26. Aso, «Paulo Orosio», 2011, 110.

27. Frighetto, «A Hispania visigoda", 2013, 75.

28. Van Nuffelen, "Orosius and the Rhetoric", 2012, 178.

29. Bodelón, "Orosio: una filosofia", 1997, 62.

30. Conf. Van Nuffelen, "Orosius and the Rhetoric", 2012, 180.
} 
Orósio, noto que a "Providência Divina" era um elemento que reforçava o apoio oferecido por Deus a Valentiniano I, pois isto teria garantido a paz com os burgúndios. Em conformidade com o filólogo Serafín Bodelón, enquanto Cícero propunha que o gênero histórico deveria ser imparcial, para Orósio a força motriz desde gênero era o providencialismo ${ }^{31}$. Fabbrizio Fabbrini alega que a polêmica orosiana contra os pagãos não se tratava de um problema doutrinal contra aquela filosofia, mas, sim, contra um modo popular de se entender os fatos históricos ${ }^{32}$.

Sob o ponto de vista orosiano, Deus era o motor dos processos históricos e o responsável por beneficiar os romanos com a conversão dos burgúndios. Diante da mudança religiosa, tal grupo não representaria mais perigo para os romanos. Sendo assim, o cristianismo, no caso de Orósio, especialmente aquele vinculado à corrente nicena, era um elemento de identificação e de união. Desta forma, o estrangeiro deixava de ser um elemento negativo na obra orosiana e ganhava o benefício de ser cristão. Tal construção discursiva ajudou a fundamentar a noção de que o império deixava de ser romano para se tornar um império cristão, mensagem, esta, difundida por muitos escritores eclesiásticos e que baseia a afirmação de Antonio José Meseguer Gil sobre uma síntese romano-cristã ${ }^{33}$. Através da propagação do cristianismo aos estrangeiros, segundo o sacerdote hispano, o mundo poderia esperar uma pax christiana, liderada por uma igreja universal, em vez do Império romano ${ }^{34}$.

A atenção de Valentiniano I à construção de fortificações nas fronteiras com o Reno e com o Danúbio para a proteção das terras romanas contra tribos estrangeiras, elogiadas nos panegíricos de autoria do senador Quinto Aurélio Símaco ${ }^{35}$, não foram consideradas na obra orosiana. Interessava a Orósio, sim, exaltar a crença cristã do governante do Império e o favorecimento de Cristo com relação a este líder ao recompensá-lo com o trono após a morte de Joviano e com a paz com os burgúndios, obtida pela Providência Divina. Por isso, o autor selecionou determinados acontecimentos e estabeleceu uma conexão entre eles. Desta forma, através dos fatos e dos recursos retóricos escolhidos para narrar a história de Valentiniano I, Orósio elaborou e propagou a imagem do que considerava ser um exemplo de imperador, um governante protegido por Cristo e defensor dos romanos contra povos estrangeiros.

31. Bodelón, "Orosio: una filosofia", 1997, 60.

32. Fabbrini, "Orosio: uno storico", 1979, 87.

33. Meseguer Gil, "A obra histórica», 2017, 96.

34. Merrills, "Orosius", 2005, 43.

35. Laudatio in Valentinianum Seniorem Augustum Prior (369 d.C.) e Laudatio in Valentinianum Seniorem Augustum Altera (370 d.C.). 


\section{VALENTE: UM EXEMPLO NEGATIVO NA OBRA OROSIANA}

Valente, batizado e persuadido pelo bispo Eudoxio, defensor do dogma ariano, declinou em uma cruel heresia; mas por um longo tempo, enquanto pressionado pela autoridade de seu irmão ainda vivo, nem cometeu uma persuasão hostil nem contaminou seu poder com suas vontades ${ }^{36}$.

Desta maneira o imperador Valente, irmão de Valentiniano I, foi apresentado ao público de Orósio. Novamente, a primeira característica destacada pelo autor foi a religião do augusto, o cristianismo ariano, qualificado pelo presbítero como "uma cruel heresia» (saeuissimam haeresim). Neste ínterim, relembro alguns atributos do autor: um defensor da fé nicena, detentor da habilidade da escrita e possuidor de um espaço para que seu texto fosse recebido, sendo estes últimos dois atributos elementos diferenciais dentro de uma sociedade na qual a escrita estava restrita a um pequeno grupo.

No excerto, sob o ponto de vista de um cristão niceno, Orósio exprimiu seu julgamento com relação ao arianismo, tratando este dogma como "cruel» e "herético». Noto que, embora o autor tenha se comprometido a compor sua obra contra os pagãos, conforme o título indicava, Historiae adversus paganos, ele também escrevia contra aqueles cristãos que não compartilhavam a fé que ele acreditava ser verdadeira (ortodoxa) e universal (católica) ${ }^{37}$, ou seja, fé a nicena.

De origem grega, a palavra "ortodoxia» (orthodoxía) refere-se à doutrina apresentada como verdadeira. Durante a Antiguidade, entretanto, as classificações das religiões consideradas "ortodoxas» e, por oposição, "heréticas» foram frequentemente reelaboradas conforme a influência que líderes religiosos desempenhavam nos círculos de poderes imperiais e/ou a crença defendida pela própria figura imperial. Entendo, portanto, que estes termos exigiam a organização constante de discursos que, através de construções retóricas, identificavam o que era ser ortodoxo, ou seja, seguidor da fé acatada como verdadeira. Concomitantemente, estas elaborações diferenciavam o herege, marcado como aquele que acreditava em crenças entendidas como falsas por quem erigia tais discursos. Nesta circuntância, é imprescindível que "ortodoxias» e "heresias» sejam analisadas

36. Or., Hist., VII, 32, 6: "Valens ab Eudoxio episcopo, Arriani dogmatis assertore, et baptizatus et persuasus, in saeuissimam haeresim declinauit; sed malignam insectationem diu texit nec uoluntati potestatem admiscuit, quoad niuentis fratris auctoritate conpressus est.

37. "Católica" (katholikós) é uma palavra de origem grega que significa "mundial", «universal». 
como "conceitos performáticos», conforme sugestão da historiadora Caroline Humfress ${ }^{38}$.

Logo, mais do que uma época de triunfo do cristianismo, entendido neste caso no singular, como uma única religião, os séculos IV e V foram marcados por debates e discursos que criavam e propagavam diretrizes favoráveis a vários cristianismos, ao passo que depreciavam outras religiões, inclusive cristãs. Sim, cristianismos plurais os quais impulsionaram querelas, conversas e a realização de concílios que buscavam solucionar questões dogmáticas. Orósio estava imerso neste contexto enquanto vivia e escrevia. Ele foi um dos autores eclesiásticos a anunciar a veracidade da crença nicena. Neste interim, concordo com a afirmação da historiadora Maria Sonsoles Guerras de que «a História de Orósio é, melhor do que história, uma apologia ao cristianismo ${ }^{39}$, e acrescento, no caso dos livros dedicados à dinastia valentinianas, uma apologia ao cristianismo niceno, visto que o arianismo seguido por Valente, foi rechaçado pelo autor e tratado como uma "cruel heresia".

Em conformidade com as argumentações orosianas, observo que era importante realçar a religião dos augustos e gerar exemplos para a audiência das Historiae. Os governantes seriam modelos para seus súditos. No caso de Valentiniano I, um modelo positivo, afinal, o hispano divulgou que o augusto renunciara sua posição militar junto a Juliano em nome da religião e que havia sido presenteado por Cristo ao ascender à posição de imperador. Já Valente, por ser ariano, teve seu registro enaltecido por infortúnios, o que produzia um modelo negativo, que deveria ser evitado pelo público de Orósio, inclusive pelo augusto que governava as terras romano-ocidentais quando estes livros foram produzidos, Honório (393423). A comparação era uma técnica retórica e para executá-la, era necessário um ponto de referência procedente de um passado ilustre e que era utilizado como forma de exemplo. Desta maneira, a história era incorporada à educação retórica através destes exemplos ${ }^{40}$. Assim como os estrangeiros eram o oposto dos romanos, um governante ruim se contrapunha ao bom. Tal construção retórica facilitava ao público o entendimento da mensagem orosiana, alimentando suas afirmações teóricas e ajudando o autor a atingir objetivos específicos.

Orósio registrou o envio por Valente de tribunos e soldados ao Egito e a outras terras para forçar os monges a se alistarem no exército, gerando

38. Humfress, «Ortodoxy», 2007, 220-222.

39. Guerras, «Paulo Orósio», 1989, 127.

40. Van Nuffelen, "Orosius and the Rhetoric", 2012, 63-64. 
uma nova forma de perseguição ${ }^{41}$. Amiano Marcelino e Sozomeno registram as perseguições de Valente a filósofos cristãos e não cristãos ${ }^{42}$. Segundo Amiano, o augusto não se importava em investigar se as denúncias recebidas eram verdadeiras e infligia punições mesmo na ausência de provas $^{43}$. Conforme Sozomeno, tanto filósofos eclesiásticos como pagãos foram quase todos mortos na época de Valente ${ }^{44}$.

Noto, portanto, que tanto para autores cristãos, como Sozomeno e Orósio, quanto para o estrategista Amiano Marcelino, Valente foi apresentado como um mal imperador, um governante que colocava seus interesses acima das suas responsabilidades imperais. Todavia, ele não se tornou augusto apenas pela vontade de seu irmão. Antes desta responsabilidade, ele já havia sido protector domestivus sob os governos dos imperadores Juliano e Joviano ${ }^{45}$. Não era, portanto, um indivíduo mal preparado para assumir encargos político-administrativos. O recente trabalho do historiador Gilvan Ventura da Silva questiona a imagem do augusto promovida sob as convicções e interesses destes autores antigos e ressalta a importância da construção do Fórum de Valente para estabelecer uma identidade própria da população de Antioquia, demonstrando, deste modo, o comprometimento deste governante com seus súditos ${ }^{46}$.

Em sua Historiae adversus paganos, Orósio manteve a imagem negativa de Valente, reportada por Amiano, entretanto, a narrativa elaborada pelo presbítero para construir sua versão da figura imperial exaltava as dificuldades imputadas pelo augusto aos cristãos. Dificuldades, estas, qualificadas pelo autor como "persuasão hostil» e "perseguição". Valente havia sido escolhido por seu irmão para compartilhar o poder imperial e governar as terras romano-orientais. O autor hispano destacou que era devido à autoridade do imperador ocidental que Valente não impunha sua hostilidade contra os nicenos ${ }^{47}$. Imediatamente após a morte de Valentiniano I, em 375, o imperador das terras orientais, então, passou a agir, segundo Orósio, com "desenfreada audácia» ${ }^{48}$. A escolha das palavras com que o autor descreveu o governante nutria a imagem negativa do augusto e esvaziava sua autoridade, gerando um modelo negativo que deveria ser evitado pelo atual augusto e por aqueles que viriam despois.

41. Or., Hist., VII, 33, 3: «alio nomine persecutionis».

42. Am., Res Gestae, XXIX, 1,20-44; 2. Soz., HE, VI, 35.

43. Am., Res Gestae, XXIX, 1, 20.

44. Soz., $H E$, VI, 35.

45. Jones, PLRE I, 1971, 930.

46. Silva, "A cidade, o imperador", 2020.

47. Or., Hist., VII, 33, 1.

48. Or., Hist., VII, 33, 1: «Ilico uelut effrenata libertatis audacia...". 
Ainda de acordo com a obra orosiana, Valente teria sido o responsável por permitir que os godos entrassem nas terras romanas portando suas armas e sem assinar nenhum tratado ${ }^{49}$. A relação estreita que, ao longo do Império, os romanos passaram a estabelecer com povos estrangeiros era vista com maus olhos pelo presbítero - e não só por ele. Os acordos que traziam benefícios para os romanos eram imprescindíveis para que este relacionamento aplacasse a tradição expansionista romana. Conforme Orósio, Valente não teria requerido tais acordos. Contudo, mesmo que Amiano Marcelino tenha edificado uma imagem negativa deste imperador, ele redigiu uma outra versão sobre estes acontecimentos. O autor alegou que o augusto inicialmente foi reticente ao pedido dos godos para se abrigarem na Trácia, porém, em seguida, consentiu que eles se assentassem em terras romanas em troca de recompensas e ajuda militar ${ }^{50}$. Renan Frighetto, historiador brasileiro das chamadas monarquias romano-bárbaras, considera que Valente desejava manter este grupo na condição de aliados dos romanos, uma prática comum naquela época. Para tanto, o imperador estabeleceu com os godos acordos com benefícios e obrigações, entre elas, a participação em campanhas militares ${ }^{51}$. Tais acordos, de fato, não foram respeitados pelos líderes godos Fritigerno e Alavivo, que se uniram contra as tropas de Valente. Os enfrentamentos entre estas tribos estrangeiras e suas aliadas contra os soldados romanos culminaram com a batalha de Adrianópolis, em 378. Nela, Valente foi morto.

Embora registros quase contemporâneos aos acontecimentos tivessem atestado a intenção de Valente de exigir dos estrangeiros benfeitorias para os romanos, isto foi negado por Orósio. O autor, ao contrário, imputou a Valente uma conduta inapropriada a um augusto: a permissão da entrada dos godos nos territórios romanos sem acordos, o que acarretou ações maléficas causadas por este grupo. Ao atribuir tal comportamento ao governante, o presbítero continuava a edificar uma avaliação contraproducente de Valente para sua audiência, uma vez que o imperador havia agido contra os interesses romanos e em prol dos estrangeiros. Nesta circunstância, não só a imagem negativa de Valente foi realçada, como também foi reforçada a ideia pejorativa e a figura inimiga que o autor propagava sobre os povos estrangeiros, neste caso, encarnado nos godos.

O julgamento do presbítero desfavorável a Valente culminou com o registro da trágica morte do augusto:

49. Or., Hist., VII, 33, 10.

50. Am., Res Gestae, XXXI, 4, 3-4.

51. Frighetto, "A antiguidade tardia", 2012, 124. 
O próprio imperador, quando ferido por uma flecha, recuou e se pôs em fuga, depois de haver chegado ali com dificuldades, na pequena casa de uma vila, foi descoberto pelos inimigos que o perseguiam e foi consumido quando aqueles colocaram fogo na casa; e para o testemunho da punição que recebeu e para que a ira divina servisse de exemplo terrível para a posteridade, ainda careceu do que é comum a todos, a sepultura ${ }^{52}$.

O autor iniciou este trecho novamente depreciando as ações do governante que, em meio a uma grande batalha, fugiu e se escondeu. Uma prática certamente comum aos líderes militares que percebiam uma situação de derrota. Porém, um elemento discursivo pejorativo, especialmente quando ligado àquele que deveria ser o mais poderoso líder dos romanos, o imperador. Em seguida, Orósio evidenciou que a morte de Valente foi um castigo imposto pela ira divina. A sentença que marcava o intuito desta narrativa: que a punição e a morte desonrosa do augusto "servisse de exemplo para a posteridade». Retomo a noção de que o autor escrevia para proporcionar ao público modelos que deveriam ser seguidos ou repelidos: Valentiniano I havia sido premiado por Cristo e, por oposição, Valente havia sido punido e sofrido com a ira divina. Estas elaborações baseadas na contraposição promoviam o entendimento da audiência orosiana e, por consequência, faziam com que esta mensagem fosse passada de boca em boca e alcançasse um público ainda maior do que aquele que ouvia Orósio ou lia sua obra.

A arqueóloga Elfrieda Frank interpreta que, em Historiae adversus paganos, a morte por fogo do augusto Valente era um caso de justiça retributiva $^{53}$. Orósio selecionou dois fatos significativos que, para ele e para seu público, reprovavam as ações deste imperador: a escolha de Valente de professar o cristianismo ariano em detrimento do niceno e as chamadas perseguições aos monges ordenadas por este governante. Tais ações, na visão de um cristão niceno, teriam gerado um castigo divino.

A versão oferecida por Orósio sobre a morte deste imperador era a mesma encontrada na Res Gestae de Amiano: a busca de Valente por um esconderijo e sua morte em um incêndio ${ }^{54}$. Entretanto, Sócrates Escolástico redigiu duas possibilidades para este acontecimento: a primeira seguiu a versão de Amiano e de Orósio; a segunda sugeriria que, após se despir

52. Or., Hist., VII, 33, 15: «ipse imperator cum sagitta saucius uersusque in fugam aegre in cuiusdam villulae casam deportatus lateret, ab insequentibus hostibus deprehensus, subiecto igne consumptus est et, quo magis testimonium punitionis eius et diuinae indignationis terribili posteris esset exemplo, etiam communi caruit sepultura».

53. Frank, "Symbolic Imagery», 1966, 46.

54. Am., Res Gestae XXXI, 16, 2. 
do seu manto imperial, o augusto teria corrido para o meio da infantaria e teria sido morto junto com ela quando o inimigo dizimou este corpo militar ${ }^{55}$. Embora o autor mantivesse a história que tratava o governante como um fugitivo, na outra versão, as ações de Valente faziam jus às suas responsabilidades como protetor dos romanos, conferindo-lhe uma morte honrosa. Sócrates escreveu sua Historia Ecclesiastica sob o governo de Teodósio II (408-450), governante dos territórios romano-orientais. Ou seja, a redação de sua obra se desenvolveu coetaneamente (ou quase) a de Orósio, mas no contexto oriental do Império. Portanto, as versões oferecidas por Sócrates provavelmente faziam parte da memória social daquele momento. Conforme ele explicou: «Alguns narram que [Valente] ele pereceu no incêndio [...] Mas outros dizem que ele abandonou o manto imperial e se juntou à infantaria» (grifos meus) ${ }^{56}$.

Não é meu intuito analisar quais das versões seriam mais críveis naquele momento, nem qual seria a verdadeira. Porém, aceitando que as duas interpretações faziam parte do contexto social romano, me pergunto por que Orósio registrou apenas a versão em que Valente havia sido morto pelos inimigos em um incêndio? A morte é um elemento de conclusão biográfica, com o qual se encerra uma narrativa, e, também, é utilizada para proporcionar um exemplo ${ }^{57}$. Sendo a imagem final da pessoa apresentada, ela deveria retratar a maneira como o indivíduo vivera. Novamente ressalto as opções feitas pelo autor. A versão sobre a morte de Valente selecionada pelo presbítero se adequava ao seu objetivo de transformar este augusto em um exemplo de conduta que deveria ser evitado: um mal governante e, por isso, punido pela ira de Deus. Percebo, então, que a persuasão ocorria pela seleção dos fatos narrados, pela escolha de um repertório de saberes e de imagens da cultura coletiva e pela organização dos argumentos que compunham uma narrativa coerente com a mensagem que o autor desejava transmitir.

\section{O Cristianismo de Graciano e poucas palavras sobre Valentiniano II}

De acordo com as elaborações contidas na Historiae adversus paganos, após a morte de Valentiniano I, Valente havia se mantido como imperador das terras romano-orientais, enquanto a parte ocidental era governada por

55. Soc. Sch., HE IV, 38.

56. Soc. Sch., HE IV, 38: «Et alii quidem incêndio eum periisse narrant [...]. Alii dicunt eum abjecto imperiali habitu in medium agmen peditum se conjecisse» (Grifos meus).

57. Kolb, "The dying emperor», 2009, 105. 
Graciano. Este imperador, então, havia nomeado seu irmão, Valentiniano II, a augusto para dividir o poder de império das terras romano-ocidentais $^{58}$. Desta forma, o espaço ocidental fora dividido da seguinte maneira: Graciano era o imperador das províncias da Gália, da Britânia e da Hispania; e Valentiniano II governava Itália, Ilíria e África Pró-consular.

Contudo, o contexto em que esta nomeção aconteceu não foi pacífico. Em 367, quando tinha aproximadamente oito anos de idade, Graciano havia sido aclamado augusto por seu pai, Valentiniano I, e pelo exército. Portanto, seria de se esperar que o vazio de poder originado da morte de Valentiniano I fosse preenchido por Graciano. Porém, com a morte do imperador, Valentiniano II foi aclamado augusto pelas legiões da Ilíria, conjuntura que Frighetto interpreta como uma situação de conflito de interesses regionais na escolha do novo imperador ${ }^{59}$. Averil Cameron afirma que Valentiniano II havia sido proclamado pelo exército sem a anuência de Graciano ${ }^{60}$. O teólogo Frederick Homes Dudden sustenta que Graciano aceitou "com complacência» a ascensão de seu irmão ${ }^{61}$.

Com relação aos escritores antigos, Orósio havia seguido a mesma noção propagada por Amiano. De acordo com o estrategista, Graciano aceitou o irmão e zelou por sua eduação ${ }^{62}$. Já Sozomeno alegou que Graciano e Valente aceitaram formalmente esta aclamação, entretanto, primeiramente, tinham se mostrado descontentes com a ação dos soldados ${ }^{63}$.

Certamente, é impossível conhecermos os sentimentos de Graciano com relação a esta circunstância. Contudo, se não fosse o favorecimento de seu irmão pelos soldados da Ilíria, Graciano seria o único imperador das terras romano-ocidentais; teria seu poder comparado ao de Valente, que governava todos os territórios orientais do Império. Por um lado, é provável que a aceitação de Valentiniano II como colega de poder não tenha sido algo tão agradável para Graciano como Amiano e Orósio afirmaram. Por outro lado, naquele momento, tanto Graciano como Valente tinham sua atenção voltada às batalhas contra tribos estrangeiras, especialmente contra os godos que, assentados no norte da Trácia, limitavam cada vez mais as fronteiras romanas. Neste caso, era mais favorável aceitar a divisão do poder com um outro membro da família do que lidar com uma situação de usurpação. Observo, aqui, o silêncio do autor como um elemento retórico para a construção de sua narrativa. Não era a intenção

58. Or., Hist., VII, 32, 15.

59. Frighetto, "A antiguidade tardia", 2012, 124.

60. Cameron, «El Bajo Imperio», 2001, 66.

61. Dudden, "The life and Times", 1935, 86.

62. Am., Res Gestae XXX, 10, 6 .

63. Soz., HE VI, 36. 
do presbítero debater os conflitos ocorridos durante a ascenção de Valentiniano II a augusto, mas, sim, exaltar a parceria que Graciano se propôs a realizar com seu irmão mais novo, um fato que reforçava a bondade, a preocupação com o Império e outros aspectos cristãos de Graciano.

Ainda segundo as elaborações orosianas, Graciano confiava no poder de Cristo, por isso, havia se lançado em uma batalha contra os inimigos que estavam em maior número e conseguido uma grande vitória para os romanos ${ }^{64}$. Orósio mencionava os enfrentamentos travados contra os lentienses (um ramo dos alamanos), em 378. Enfrentamentos narrados também por Amiano que ressaltou, inclusive, o tamanho do exército inimigo, formado por quarenta ou mesmo setenta mil homens, restando, após a batalha realizada em Argentária, cerca de cinco mil ${ }^{65}$. Esta é a última notícia que se tem sobre os lentienses, por isso, considera-se que Graciano exterminou esta tribo.

À diferença dos registros de Amiano, que exaltaram as estratégias militares, os embates entre os exércitos e a coragem que tal vitória trouxe a Graciano $^{66}$, Orósio salientou a confiança do imperador em Cristo. A providência divina teria, novamente, auxiliado um governante julgado correto pelo autor. Assim como, conforme Orósio, teria sido a providência divina a alcançar a paz conseguida junto aos burgúndios, na época de Valentiniano I, com Graciano, mais uma vez a ajuda de Deus teria trazido a vitória aos romanos. De acordo com Guerras, a partir do elemento da providência divina, Orósio anunciava um Império romano universal e cristão "Como o caminho a ser seguido para se chegar ao verdadeiro Império" ${ }^{67}$.

Ponderando sobre esta afirmação, observo que, ao registrar as histórias sobre os imperadores valentinianos, o presbítero construiu uma narrativa que identificava estes governantes - e consequentemente o Império romano - ao cristianismo niceno. Ao aceitar que este Império integrava os quatro grandes reinos que submeteriam todos os outros reinos ${ }^{68}$, o hispano propagava a ideia da universalidade do Império romano. Ligada à esta universalidade, segundo a obra orosiana, estaria o cristianismo niceno, visto que os corretos governantes professariam esta religião e seriam protegidos pela providência divina, aquela que beneficiara Valentiniano I e Graciano.

64. Or., Hist., VII, 33, 8.

65. Am., Res Gestae XXXI, 10, 5; XXXI, 10, 10.

66. Am., Res Gestae XXXI, 10.

67. Guerras, «Paulo Orósio», 1989, 132.

68. Sob o ponto de vista orosiano, os quatro grandes reinos são: babilônico, macedônico, africano e romano (Or., Hist., II, 4). 
Quando as crenças e as comunidades cristãs começaram a se fortalecer, os autores eclesiásticos tiveram a necessidade de legitimar sua religião e, por isso, buscaram suas origens em um passado remoto e amplo, ligado às histórias do Antigo Testamento. Tal estratégia proporcionava o tom «universal» dos escritos cristãos. As Historiae adversus paganos foram consideradas a primeira história universal cristã ${ }^{69}$. A universalidade com que Orósio descreveu o Império após Augusto contrastava com a apresentação dos demais impérios, uma vez que cada um deles estava limitado a uma região. Por outro lado, através da retórica da geografia, o autor celebrou o Império romano como sendo potencialmente universal uma vez que estava vinculado ao cristianismo ${ }^{70}$. Nesta conjuntura, percebo que a história do Império cristão narrada pelo autor estava orientada para o bem universal que tal religião propunha. Para incrementar suas afirmações teóricas e anunciar esta mensagem, o presbítero apresentou a providência divina e, consequentemente, os benefícios que Deus concedia a determinados augustos como um caminho para se alcançar esta universalidade.

Ainda sobre Graciano, Orósio observou que, impulsionado pela morte de Valente, o imperador havia escolhido Teodósio I para governar as terras romano-orientais. E desta vez comparou Graciano a Nerva ${ }^{71}$, que havia partilhado seu poder de império com Trajano, um governante de origem hispana assim como Teodósio. Sobre Nerva, Orósio mencionou seu curto tempo de governo, a escolha de Trajano como sucessor e sua morte por uma enfermidade ${ }^{72}$. Já sobre Trajano, o autor o dispôs como auxiliado pela providência divina e responsável por reorganizar um Império arruinado $^{73}$

No caso de Graciano, quando o presbítero o comparava a Nerva, então, realçava o compartilhamento de poder entre este governante e Teodósio I, não virtudes ou vícios imperais. Todavia, esta ação de Graciano em prol de Teodósio mereceu o registro do autor. O governante das terras orientais recebeu muitos elogios na Historiae adversus paganos e, inclusive, foi comparado a Trajano, um imperador virtuoso na versão orosiana $^{74}$. Orósio elaborou para Teodósio uma imagem repleta de virtudes que propagava a condição meio sagrada, meio humana deste

69. Alonso-Nuñez, «La metodologia histórica», 1994, 375.

70. Merrills, "Orosius", 2005, 54-68.

71. Or., Hist., VII, 34, 2.

72. Or., Hist., VII, 11.

73. Or., Hist., VII, 11, 1.

74. Or., Hist., VII, 34, 3. A respeito de Teodósio na Historiae adversus paganos sugiro a leitura do artigo: Frighetto, "A imagem de Teodósio», 2005, 25-37. 
governante $\mathrm{e}^{75}$. Os imperadores cristãos antes de Teodósio foram discretamente apresentados pelo hispano, nem mesmo Constantino recebeu muita atençã $\mathrm{O}^{76}$. A partir deste momento das Historiae, apesar do autor ainda traçar alguns registros sobre Graciano e Valentiniano II, o protagonismo de Teodósio I era evidente.

Sobre Graciano, Orósio citou sua morte pelo usurpador Máximo, facilitada por um episódio de traição ${ }^{77}$. Sozomeno e Zosimo esclareceram que, por ordem de Máximo, seu general Andragatio, perseguiu Graciano e o matou ${ }^{78}$. Coetaneamente à morte deste imperador, Ambrósio, bispo de Milão, havia acusado Máximo de organizar o assassinato de Graciano ${ }^{79}$. Orósio não ofereceu detalhes sobre a morte deste augusto, somente a mencionou e passou a tratar das ações de Teodósio I para deter Máximo e seu exército. Embora a morte de Graciano não tenha assumido, para Orósio, nenhum tipo de exemplo, ela serviu como motivo para impulsionar as ações teodosianas que buscaram a represália em nome do imperador recentemente falecido e de seu irmão, Valentiniano II, que havia se refugiado nos territórios orientais do Império.

Seguindo este caminho narrativo, o protagonista das histórias orosianas sobre Valentiniano II foi Teodósio I. Conforme o presbítero, este imperador havia sido o responsável por vingar a morte de Graciano e reconquistar o poder de império dos territórios romano-ocidentais para o jovem Valentiniano ${ }^{80}$. Desta maneira, o autor transformou Valentiniano II em um personagem passivo que recebeu o poder de império de Teodósio e "conduziu em paz ao estar em uma situação política (republica) tranquila ${ }^{81}$. Uma tranquilidade que, de acordo as elaborações retóricas do presbítero, teria sido alcançada através de ações teodosianas, não de Valentiniano II.

O protagonismo oferecido por Orósio e outros escritores antigos a Teodósio alimentou por séculos uma historiografia preocupada em analisar o governo deste imperador e que poucas vezes trouxe à luz governantes que compartilharam o poder com este augusto. Todavia, visto que os processos históricos são tão multifacetados, a escrita da História também deve primar por esta multiplicidade (de versões, personagens, culturas, geografias...). É certo que sem documentos não é possível se fazer

75. Frighetto, "A imagem de Teodósio", 2005, 28.

76. Van Nuffelen, "Orosius and the Rhetoric", 2012, 161.

77. Or., Hist., VII, 34, 9.

78. Soz., $H E$ VII, XIII; Zos. Hist., IV, 35, 6.

79. Amb., Ep. 30 (24), 10-11.

80. Or., Hist., VII, 35.

81. Or., Hist., VII, 35, 10: «ubi cum tranquilla republica in pace ageret». 
Histórias. Entretanto, os silêncios dos documentos sempre respondem ao contexto em que foram elaborados. Recordo que quando se dedicava a escrita de sua Historiae adversus paganos, Orósio vivia em um Império romano governado no Ocidente por Honório, filho mais novo do falecido imperador Teodósio I. O exemplo que Orósio criava sobre Teodósio deveria inspirar o herdeiro sanguíneo do trono, bem como seus súditos.

Além de exaltar a figura do pai do atual augusto ocidental, o autor também louvava as ações de um imperador que beneficiou o cristianismo niceno. Nesta circunstância, era esclarecedora a escolha pelo protagonismo de Teodósio I em detrimento de Valentiniano II. Assim que se tornou imperador das terras orientais, Teodósio deixou claro, com a promulgação do Edito de Tessalônica $(\text { de } 380)^{82}$, que professava o credo niceno ${ }^{83}$.

Por outro lado, no início de seu governo, Valentiniano II defendia o cristianismo ariano. Somente após a morte de sua mãe, Justina, este augusto aproximou-se de Ambrósio, bispo da cidade de Milão que anunciava o niceismo como sendo a verdadeira fé cristã. Saliento que, mesmo depois de assinar, juntamente com Teodósio e Graciano, o Edito de Tessalônica, Valentiniano II exigiu que Ambrósio entregasse uma das igrejas milanesas aos arianos. Episódio que ficou conhecido na historiografia como o "Conflito das Basílicas", ocorrido provavelmente entre 385 e 386. Diante deste contexto, era elucidativa a opção de Orósio em oferecer ênfase à figura de Teodósio e não à de Valentiniano II.

Com relação à "situação política tranquila" " $^{84}$ que, de acordo com o presbítero, este augusto haveria desfrutado após retomar o poder de império, não era exatamente assim. Valentiniano II havia se deslocado para os Alpes da Itália com o intuito de combater inimigos estrangeiros. Ao chegar à cidade de Viena, foi morto ao enfrentar o exército liderado pelo magister militum Arbogasto, o que evidenciava o descontentamento de um líder militar romano, de origem franca, e de seus apoiadores com relação ao governo de Valentiniano II. Longe da tranquilidade registrada pelo hispano, e que seria um presente alcançado por Teodósio, o augusto

82. C. Th. XVI, 1,2 .

83. Com relação do Edito de Tessalônica de 380, não compartilho a ideia de que esta tenha sido uma constituição válida para todas as terras romanas. Observo, sim, seu caráter regional, voltado à cidade de Constantinopla. Compreendo-o, também, como uma maneira de Teodósio se diferenciar de seu antecessor Valente quando assumiu a posição de augusto das terras romano-orientais. Sobre o caráter regional do Edito de Tessalônica, sugiro a leitura de: Testa, «La politica religiosa di Teodosio I», 1996, 323-361; Escribano Paño, "Emperadores y leyes", 2014, 61-82.

84. Or., Hist., VII, 35, 10. 
das terras ocidentais lidava com inimigos advindos de fora e de dentro de suas terras. Situações, estas, que foram silenciadas por Orósio. Como observado, os argumentos orosianos explicitaram as práticas teodosianas em detrimento das obras de Valentiniano II. Estas elaborações diminuíram a importância de um imperador que dividiu o poder de império com Teodósio e que, durante parte de sua vida, protegeu o arianismo. As benfeitorias teodosianas, retoricamente organizadas por Orósio, ofuscavam a imagem de Valentiniano II, respondiam aos propósitos de exaltar o cristianismo niceno professado por Teodósio e, portanto, não eram discursos neutros nem "mensagens inocentes", como alertou Laird.

\section{CONSIDERAÇÕES FINAIS}

Para se compreender a imagem construída por Orósio a respeito da dinastia valentiniana se faz necessário conhecer o contexto no qual a Historiae adversus paganos foi escrita e a formação do autor. Ponderar que a obra foi produzida na época do imperador Honório, observar a defesa do cristianismo niceno por parte do presbítero e sua fuga da Península Ibérica impulsionada pelas ondas de migrações estrangeiras foram estratégias essenciais para as interpretações promovidas neste artigo. A preocupação com as elaborações retóricas levadas a cabo pelo hispano e a busca pelos significados por ele construídos também motivaram minhas investigações.

Com estes elementos em mente, saliento que, fundamentado em suas crenças religiosas cristãs nicenas, Orósio elaborou uma imagem dupla dos governantes desta dinastia: enquanto Valentiniano I e Graciano eram "imperadores cristãos", como descreveu o próprio autor ao apresentar tais augusto; Valente foi desvalorizado ao seguir "uma cruel heresia», visto que compartilhava o dogma ariano. Valentiniano II, por sua vez, foi tratado como um personagem coadjuvante da história de Teodósio I, sendo mencionado como um sujeito passivo e tendo suas ações emudecidas pelo autor. Ou seja, os governantes conhecidos por professarem a fé nicena receberam a atenção e os elogios do presbítero, sendo anunciados como líderes romanos. Já aqueles que tinham prejudicado os cristãos nicenos foram detratados, no caso de Valente, ou silenciados, no caso de Valentiniano II. Desta maneira, a ênfase das Historiae adversus paganos (VII, 32-35) estava nas ações dos augustos com relação ao niceismo e na força civilizadora que esta crença religiosa, segundo o ponto de vista do hispano, proporcionava ao Império romano.

Além da crença religiosa, a atitude dos imperadores com relação aos povos estrangeiros também serviu de base para que o autor exaltasse a 
imagem de Valentiniano I e rejeitasse a de Valente. Tais argumentos fortaleceram, respectivamente, um modelo positivo e um negativo erigidos pelo presbítero, propondo àquela audiência, inclusive ao augusto Honório, exemplos de conduta e alicerçando as noções teóricas defendidas pelo autor.

Neste ínterim, noto que Orósio foi um dos escritores eclesiásticos responsáveis, por um lado, por intensificar o discurso que pouco a pouco creditava ao cristianismo niceno sua ortodoxia e universalidade e, por outro lado, foi mais um dos homens habilidosos com as letras a criar e divulgar uma imagem pejorativa dos povos estrangeiros.

\section{Agradecimentos}

Agradeço imensamente à Profa. Dra. Margarida Maria de Carvalho por me acompanhar neste processo de intensas pesquisas e debates que enriquecem meu pós-doutorado.

Agradeço também à Fundação de Amparo à Pesquisa do Estado de São Paulo por financiar meus estudos de pós-doutorado no Brasil (processo número 2016/20942-9) e no exterior (processo BEPE-Espanha 2017/26939-2, processo BEPE-Itália 2018/03187-8). Sem este apoio, esta pesquisa não seria possível.

\section{Bibliografia}

\section{Documentos}

Augustinus. Epistola 166. En Augustinus. Epistolae. MPL 33, col. 0061-1094. Disponible en: https://documentacatholicaomnia.eu/02m/0354-0430, Augustinus,_Epistolae,_MLT.pdf Acceso en: 11/01/2021.

Ambrose of Milan. Political letters and speeches. Translated with an introduction and notes by J. H. W. G. Liebeschuetz with assistance of Carole Hill. Liverpool: Liverpool University Press, 2010.

Amianus Marcelinus. Historia. Edición de María Luisa Harto Trujillo. Madrid: Ediciones Akal, 2002.

Amianus Marcelinus. Res Gestae. Cambridge: Ed. Rolfe, 1963.

Gennadius Massiliensis. De viris illustribus. MPL 58, col. 1059-120. Disponible en: https://documentacatholicaomnia.eu/02m/0450-0550, Gennadius_Massiliensis,_Liber_De_Scriptoribus_Ecclesiasticis,_MLT. pdf Acceso en: 11/01/2021. 
Mommsen, Theodor y Paul Martin Meyer. Theodosiani. Libri XVI. Cum Constitutionibus Sirmondianis et Leges Novellae ad Theodosianum Pertinentes, vol. I (pars prior). Berolini: Apud Weidmannos, 1905. (Codex Theodosianus XVI).

Paulus Orosius. Adversus paganos historiarum libri septem. Thorunii: Sumptibus Ernesti Lambeccil, 1856.

Paulus Orosius. Historias (libros I-IV). Traducción y notas de Eustaquio Sánchez Salor. Madrid: Editorial Gredos, 1982.

Paulus Orosius. Historias (libros V-VII). Traducción y notas de Eustaquio Sánchez Salor. Madrid: Editorial Gredos, 1982.

Socrates Scholasticus. The Ecclesiastical History. Revised, with notes by

A. C. Zenos. Disponible en: http://www.ccel.org/ccel/schaff/npnf202. html. 27/22/2020.

Socrates et Sozomenus. Historia Ecclesiastica. Patrologiae Graecae Tomus LXVII. A cura di P. Migne. Henrico Valesio Interprete. Ramos Editore, 1864.

Sozomenus. Ecclesiastical History: a bistory of the Chrch in nine books, from 324 to 440. London: Samuel Bagster and Sons, 1846.

Suetonius Tranquillus. Vidas de los doce Césares, vol. I. Traducción de Rosa María Agudo Cubas. Madrid: Editorial Gredos, 1992. (Suetonius, Divus Augustus)

Zosimus. Nueva Historia. Introducción, traducción y notas de José María Candau Morón. Madrid: Editorial Gredos, 1992.

\section{Bibliografia}

Alonso-Nuñez, José Miguel. "La metodología histórica de Paulo Orosio". Helmantica vol. 45, n. ${ }^{\circ}$ 136-138 (1994): 373-379.

Aso, Graciela Gómez de. "Paulo Orosio: una interpretación de la historiografía providencialista cristiana ante la caída de Roma en el 410". De Rebus Antiquis Año 1 (2011): 98-114.

Bodelón, Serafín. "Orosio: una filosofia de la Historia». Memorias de Historia Antigua n. 18 (1997): 59-80.

Bonamente, Giorgio. "Teodosio il Grande e la fine dell'apoteosi imperiale». Politica, religión y legislación en el Imperio Romano (ss. IV y $V$ d.C.) - Politica, religione e legislazione nell'Imperio Romano (IV e V secolo d.C.), María Victoria Escribano Paño e Rita Lizzi, 17-36. Bari: Edipuglia, 2014.

Cameron, Averil. El Bajo Imperio romano (284-430 d. C.). Madrid: Ediciones Encuentro, 2001. 
Dudden, Frederick Homes. The life and Times of St. Ambrose, vol. I. Oxford: The Clarendon Press, 1935.

Escribano Paño, María Victoria. «Emperadores y leyes en época teodosiana (Codex Theodosianus 16, 5, De Haereticis)». En Política, religión $y$ legislación en el Imperio Romano (ss. IV y $V$ d.C.) - Politica, religione e legislazione nell'Imperio Romano (IV e V secolo d.C.), Ed. María Victoria Escribano Paño e Rita Lizzi, 61-82. Bari: Edipuglia, 2014.

Fabbrini, Fabrizio. Orosio: uno storico. Roma: Edizione di Storia e Letteratura, 1979.

Frank, Elfrieda. «Symbolic Imagery in Ammianus Marcellinus». Classical Bulletin 42 (1966): 46-47.

Frighetto, Renan. "A imagem de Teodósio nas Historiae Adversus Paganos VII, 34-35 de Paulo Orósio». Stylos, n. ${ }^{\circ} 14$ (2005): 25-37.

Frighetto, Renan. A antiguidade tardia: Roma e as monarquias romano-bárbaras numa época de transformações (Séculos II - VIII). Curitiba: Juruá, 2012.

Frighetto, Renan. "A Hispania visigoda (séculos VI-VII) e a Antiguidade Tardia: algumas considerações». Revista Territórios \& Fronteiras, vol. 6, n. ${ }^{\circ} 1$ (2013): 63-96.

Guerras, Maria Sonsoles. "Paulo Orósio e o providencialismo no marco do Império Romano". Classica - Revista Brasileira de Estudos Clássicos vol. 2, n. ${ }^{\circ} 1$ (1989): 123-133.

Humfress, Caroline. Ortodoxy and the Courts in Late Antiquity. New York: Oxford University Press, 2007.

Jones, A. H. M., J. R. Martindale e J. Morris. The prosopografy of the Later Roman Empire (A.D. 260-395) (PLRE I), vol. 1. Cambridge: Cambridge University Press, 1971.

Kolb, Anne. "The dying emperor: depictions of death and their meaning". En Formae mortis: el tránsito de la vida a la muerte en las sociedades antiguas, editado por Francisco Marco Simón, Francisco Pina Polo e José Remesal Rodríguez, 101-112. Barcelona: Universitat de Barcelona, 2009.

Laird, Andrew. "The rhetoric of Roman historiography". En Andrew Feldherr, (ed.). The Cambridge Companion to the Roman Historians. Cambridge: Cambridge University Press, 2009: 197-213.

Merrills, A. H. "Orosius". En History and Geography in Late Antiquity, 35-99. Cambridge: Cambridge University Press, 2005.

Meseguer Gil, Antonio José. «La obra histórica de Paulo Orosio y sus diferencias con Agustín de Hipona: transmisión de conceptos historiográficos en la Antigüedad Tardía.. Revista Onoba n. 5 (2017): 89-101. 
Silva, Gilvan Ventura da. "A cidade, o imperador e os sentidos da memória: o governo de Valente em Antioquia (371-378)». História - São Paulo vol. 39 (2020): 1-19. Disponible en: https://www.scielo.br/pdf/ his/v39/1980-4369-his-39-e2020048.pdf. Acceso: 08/12/2020.

Tamas, Hajnalka. "Valentinian I, christianissimus imperator? Notes on a Passage of the Passio Pollionis (BHL 6869)». Vigiliae Christianae 68/1 (2014): 82-97.

Testa, Rita Lizzi. «La politica religiosa di Teodosio I. Miti storiografici e realtà storica». En Atti della Accademia Nazionale dei Lincei, 323-361. Roma: Rendiconti, 1996.

Van Nuffelen, Peter. Orosius and the Rhetoric of History. Oxford: Oxford University Press, 2012.

Woodman, Anthony John. Rhetoric in Classical Historiography: Four Studies. Taylor e Francis, 2004. (Edição Kindle)

Zanker, Paul. Augusto y el poder de las imágenes. Madrid: Alianza Editorial, 2005. 